\title{
Effect of Mn Doping Concentration on Structural, Morphological and Optical Studies of ZnO Nano-particles
}

\author{
V. D. Mote ${ }^{1, *}$, J. S. Dargad ${ }^{1}$, B. N. Dole ${ }^{2}$ \\ ${ }^{1}$ Department of Physics, Dayanand Science College, Latur-413 531, Maharashtra, India \\ ${ }^{2}$ Advanced Materials Research Laboratory, Department of Physics, Dr. Babasaheb Ambedkar Marathwada University, Aurangabad-431 \\ 004, Maharashtra, India \\ *Corresponding author: vmote.physics@gmail.com
}

Copyright @ 2013 Horizon Research Publishing All rights reserved.

\begin{abstract}
We report the crystal structure, morphology and optical properties of the $\mathrm{Zn}_{1-\mathrm{x}} \mathrm{Mn}_{\mathrm{x}} \mathrm{O}$ nanoparticles with nominal composition $(\mathrm{x}=0.00,0.05,0.10,0.15 \& 0.20)$ were synthesized by sol-gel route. The crystal structure analysis was carried out by X-ray diffraction technique (XRD), morphology and particle size was investigated using Transition electron microscopy (TEM), Optical characterization was performed using UV-VIS technique. The XRD studies show that samples have wurtzite (hexagonal) crystal structure. In addition to this XRD results also indicate no extra impurity or secondary phases are observed. The lattice parameters a and c of $\mathrm{Zn}_{1-\mathrm{x}} \mathrm{Mn}_{\mathrm{x}} \mathrm{O}$ nanoparticles increase with increasing $\mathrm{Mn}$ content which indicates that $\mathrm{Mn}^{2+}$ ions go to $\mathrm{Zn}^{2+}$ ions in the $\mathrm{ZnO}$ lattice. The atomic packing fraction (APF) increase of Mn doped $\mathrm{ZnO}$ nanoparticles with increasing $\mathrm{Mn}$ content. TEM microphotographs show that the pure and $10 \% \mathrm{Mn}$ doped $\mathrm{ZnO}$ nanoparticles are in spherical shape and their average particle size of pure and $10 \% \mathrm{Mn}$ doped $\mathrm{ZnO}$ nanoparticles are found in the range of 20-60 $\mathrm{nm}$. The optical energy band gap decreases with increasing Mn concentration, it may be owing to Mn clustering.
\end{abstract}

Keywords Nano-particles, APF, surface area to volume ratio, Cluster

\section{Introduction}

Zinc oxide $(\mathrm{ZnO})$ has attracted much attention in the last few decades due to its wide variety of application such as sensors, field-emission transistors, ultraviolet photo-detectors, biomedical systems such as ultrasensitive DNA sequence detectors [1-5]. $\mathrm{ZnO}$ is a semiconductor with a wide band gap i.e. $3.37 \mathrm{eV}$. The stable structure of $\mathrm{ZnO}$ is mostly in wurtzite structure, in which four atoms of oxygen in tetrahedral co-ordination surround each atom of zinc. Zinc oxide is also used for spintronics applications with magnetic ions i.e. $\mathrm{Co}, \mathrm{Ni}, \mathrm{Mn}, \mathrm{V}$ and $\mathrm{Fe}$ doping. For this reason, $\mathrm{Mn}$ doping has valuable spin off in electrical, magnetic and optical properties of $\mathrm{ZnO}$. Thus $\mathrm{Mn}$ doped $\mathrm{ZnO}$ has become a reasonable choice for diluted magnetic semiconductor (DMS). Diluted magnetic semiconductor (DMS) materials have many unique applications such as magneto-optical, magneto-electrical and magneto-transport properties etc [6].

Different methods have been used to synthesis of nanopowders of $\mathrm{Mn}$ doped $\mathrm{ZnO}$ like sol-gel [7], co-precipitation [8], combustion [9], solid state sintering methods [10], hydrothermal synthesis [11], thermal evaporation of $\mathrm{Zn} \mathrm{[12],} \mathrm{spray} \mathrm{pyrolysis} \mathrm{[13]} \mathrm{and} \mathrm{low}$ temperature wet-chemical method [14] these methods have occurred worldwide in nanotechnology. In this study we focused on the structural, morphological and optical properties of $\mathrm{Mn}$ doped $\mathrm{ZnO}$ nanoparticles prepared by sol-gel technique. Effect of $\mathrm{Mn}$ doping on the lattice parameters, crystallite size, volume of unit cell, atomic packing fraction (APF), X-ray density and energy band gap were investigated qualitatively and quantitatively in this paper.

\section{Experimental Details}

The samples of $\mathrm{Mn}$ substituted $\mathrm{ZnO}$ with nominal compositions $\mathrm{Zn}_{1-\mathrm{x}} \mathrm{Mn}_{\mathrm{x}} \mathrm{O}$ (x = 0.00, 0.05, 0.10, $\left.0.15 \& 0.20\right)$ were synthesized by sol-gel route using high purity $(99.99 \%$ AR grade) acetates of $\mathrm{Zn}$ and $\mathrm{Mn}$ i.e. $\mathrm{Zn}\left(\mathrm{CH}_{3} \mathrm{CO}_{2}\right)_{2} .2 \mathrm{H}_{2} \mathrm{O}$ and $\mathrm{Mn}\left(\mathrm{CH}_{3} \mathrm{CO}_{2}\right)_{2} 4 \mathrm{H}_{2} \mathrm{O}$. In this procedure, to prepare pure $\mathrm{ZnO}$, the appropriate amount of Zinc acetates ( $\mathrm{Zn}$ $\left.\left(\mathrm{CH}_{3} \mathrm{CO}_{2}\right)_{2} 2 \mathrm{H}_{2} \mathrm{O}\right)$ were dissolved in $\mathrm{N}$-dimethylformamide (DMF), stirred for 3 hours using hot plate with a magnetic stirrer. The temperature was maintained at $30-40{ }^{\circ} \mathrm{C}$ for complete dissolution. It was then raised and held at $70-80{ }^{\circ} \mathrm{C}$ for 2 hours until all fluid was evaporated, then gel is obtained. These gels were heated at $150{ }^{\circ} \mathrm{C}$ for $3 \mathrm{hrs}$ in the furnace for dehydration. These precursors were ground in an agate mortar by pestle for 30 minutes to obtain fine powder. These powders placed in a $\mathrm{Al}_{2} \mathrm{O}_{3}$ crucible for sintering in furnace at $450{ }^{\circ} \mathrm{C}$ for $8 \mathrm{hrs}$ followed by furnace cooling at room 
temperature. To get the powdered sample of pure $\mathrm{ZnO}$.

For preparation of $\mathrm{Mn}$ doped $\mathrm{ZnO}$, the appropriate amounts of two precursors of Zinc acetate $\left.\left(\mathrm{ZnCH}_{3} \mathrm{CO}_{2}\right)_{2} \cdot 2 \mathrm{H}_{2} \mathrm{O}\right)$ and Manganese acetate $(\mathrm{Mn}$ $\left.\left(\mathrm{CH}_{3} \mathrm{CO}_{2}\right)_{2} 4 \mathrm{H}_{2} \mathrm{O}\right)$ were thoroughly dissolved in $\mathrm{N}$-dimethylformamide (DMF), stirred for 3 hours using hot plate with a magnetic stirrer. The temperature was maintained at $30-40{ }^{\circ} \mathrm{C}$ for complete dissolution. It was then raised and held at $70-80{ }^{\circ} \mathrm{C}$ for 2 hours until all fluid was evaporated then gel is obtained. These gels were heated at $150{ }^{0} \mathrm{C}$ for $3 \mathrm{hrs}$ in the furnace for dehydration. These precursors were ground in an agate mortar by pestle for 30 minutes to obtain fine powder. These powders placed in a $\mathrm{Al}_{2} \mathrm{O}_{3}$ crucible for sintering in furnace at $450{ }^{\circ} \mathrm{C}$ for $8 \mathrm{hrs}$ followed by furnace cooling at room temperature. This time, dark yellowish colored powders were obtained which indicate that only single phase is formed for getting the powdered samples of $\mathrm{Zn}_{1-\mathrm{x}} \mathrm{Mn}_{\mathrm{x}} \mathrm{O}$ system. The crystal structure of all the samples studied using X-ray diffractometer (Model: PW-3710) with $\mathrm{Cuk}_{\alpha}\left(\lambda=1.5406 \mathrm{~A}^{\circ}\right.$ ) radiation. It was used for recording $\mathrm{X}$-ray diffraction pattern operating at $40 \mathrm{kV}$ and $40 \mathrm{~mA}$.

To study the sample morphology, the powders were ultrasonically mixed with ethanol and suspended on a $\mathrm{Cu}$ mesh, which was the sample holder of a transmission electron microscope (TEM) operated at $200 \mathrm{kV}$ (TEMModel CM 200, SUPERTWIN). Absorption spectra of the samples in the UV-visible spectral region were recorded using UV-VIS-NIR (JASCO V 570) spectrophotometer for the determination of energy band gap of $\mathrm{Mn}$ doped $\mathrm{ZnO}$ nanocrystals.

\section{Results and Discussion}

\subsection{Structural Analysis}

The structure parameters and phase purity of pure and different concentration of $\mathrm{Mn}$ substituted $\mathrm{ZnO}$ nanoparticles sintered at $450^{\circ} \mathrm{C}$ were estimated using $\mathrm{X}$-ray diffraction (XRD). Figure 1 shows XRD patterns of pure and $\mathrm{Mn}$ substituted $\mathrm{ZnO}$ nanoparticles with nominal composition i.e. $\mathrm{x}=0.00,0.05,0.10,15$ and 0.20 samples. The diffraction peaks with intensity correspond to the plane such as (100), (002), (101), (102), (110), (103), (200), (112) and (201). It indicates that all sintered samples have hexagonal (wurtzite) crystal structure. It also has been seen that the XRD peak broadening increases with increasing Mn content, when the doping of Mn up to $20 \%$. There is no any extra peak of manganese metal, oxides, or any impurity phases were observed. It indicates that all samples are single phase. Sharma et al [15] reported that the presence of secondary phases like $\mathrm{ZnMn}_{2} \mathrm{O}_{3}$ or $\mathrm{Mn}_{3} \mathrm{O}_{4}$ in the $\mathrm{Mn}$ doped $\mathrm{ZnO}$ nanoparticles. But in our case the $\mathrm{Mn}$ ions go to $\mathrm{Zn}$ site up to $20 \%$ without changing the wurtzite crystal structure and no formation of secondary phases when the samples prepared by sol - gel route at temperature $450^{\circ} \mathrm{C}$. The reflection peaks in the diffraction patterns of $\mathrm{Mn}$ substituted $\mathrm{ZnO}$ nanoparticles are slightly shifted to lower angle as compared to the pure $\mathrm{ZnO}$ nanoparticles. It evidences the $\mathrm{Mn}^{2+}$ ions go to $\mathrm{Zn}^{2+}$ sites.

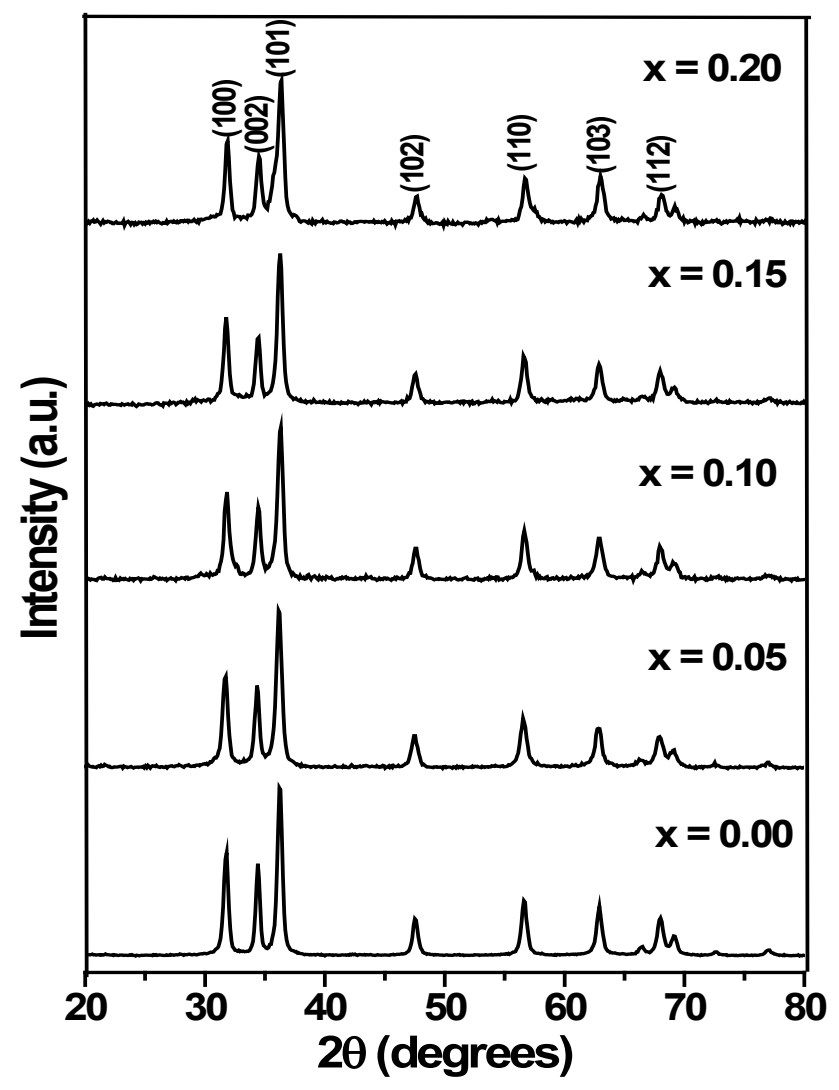

Figure 1. X-ray diffraction pattern of $\mathrm{Zn}_{1-\mathrm{x}} \mathrm{Mn}_{\mathrm{x}} \mathrm{O}$ samples.

\subsection{Lattice Parameters}

The lattice parameters a \& c of the samples were calculated using following equation.

$$
\frac{1}{d_{h k l}^{2}}=\frac{4}{3}\left[\frac{h^{2}+h k+k^{2}}{a^{2}}\right]+\frac{l^{2}}{c^{2}}
$$

Where a $\& \mathrm{c}$ are the lattice parameters, $d$ is the interplanar distance and (hkl) are the Miller indices. The values of lattice parameters are listed in table 1 . The lattice parameters go on increasing with increasing $\mathrm{Mn}$ content of $\mathrm{Zn}_{1-\mathrm{x}} \mathrm{Mn}_{\mathrm{x}} \mathrm{O}$ nanoparticles because of higher ionic radius of $\mathrm{Mn}^{2+}$ ions in comparison to the $\mathrm{Zn}^{2+}$ ions. However, the lattice parameters increase up to $20 \% \mathrm{Mn}$ doping. But Abrishami et al [16] reported that the $\mathrm{Mn}$ doping for $\mathrm{x}=15 \%$ in $\mathrm{ZnO}$ nanometer-sized crystals the lattice constant decrease, it may be due to $\mathrm{Mn}^{3+}$ and $\mathrm{Mn}^{4+}$ brings. In our case there is no reduction in the lattice parameters with increasing $\mathrm{Mn}$ up to $20 \%$ in $\mathrm{ZnO}$ nanocrystals. It indicates that, no formation of $\mathrm{Mn}^{3+}$ or $\mathrm{Mn}^{4+}$ ions in the $\mathrm{Zn}_{1-\mathrm{x}} \mathrm{Mn}_{\mathrm{x}} \mathrm{O}$ nanoparticles. The lattice parameters versus $\mathrm{Mn}$ content of $\mathrm{Zn}_{1-\mathrm{x}} \mathrm{Mn}_{\mathrm{x}} \mathrm{O}$ nanoparticles plot is shown in figure 2 . 
Table 1. The lattice parameters, crystallite size (D), volume of unit cell, X-ray density, APF and surface area to volume ratio of Mn doped ZnO samples synthesized by sol-gel route.

\begin{tabular}{|c|c|c|c|c|c|c|c|}
\hline Samples & $a\left(A^{0}\right)$ & $c\left(A^{0}\right)$ & D & $\begin{array}{l}\text { Volume } \\
\qquad(\mathrm{nm})\end{array}$ & $\begin{array}{l}X \text { - density } \\
\left(A^{0}\right)^{3}\end{array}$ & $\begin{array}{l}\text { APF } \\
\qquad\left(\mathrm{g} / \mathrm{cm}^{3}\right)\end{array}$ & $\mathrm{S} / \mathrm{V}$ ratio \\
\hline 0.00 & 3.2518 & 5.2096 & 42.53 & 47.7071 & 5.6671 & 0.75552 & 0.02605 \\
\hline 0.05 & 3.2523 & 5.2100 & 37.29 & 47.7254 & 5.6286 & 0.75445 & 0.02982 \\
\hline 0.10 & 3.2536 & 5.2112 & 35.87 & 47.7746 & 5.5865 & 0.75458 & 0.03104 \\
\hline 0.15 & 3.2540 & 5.2117 & 35.12 & 47.7909 & 5.5483 & 0.75460 & 0.03172 \\
\hline 0.20 & 3.2547 & 5.2128 & 33.64 & 47.8215 & 5.5085 & 0.75460 & 0.03316 \\
\hline
\end{tabular}

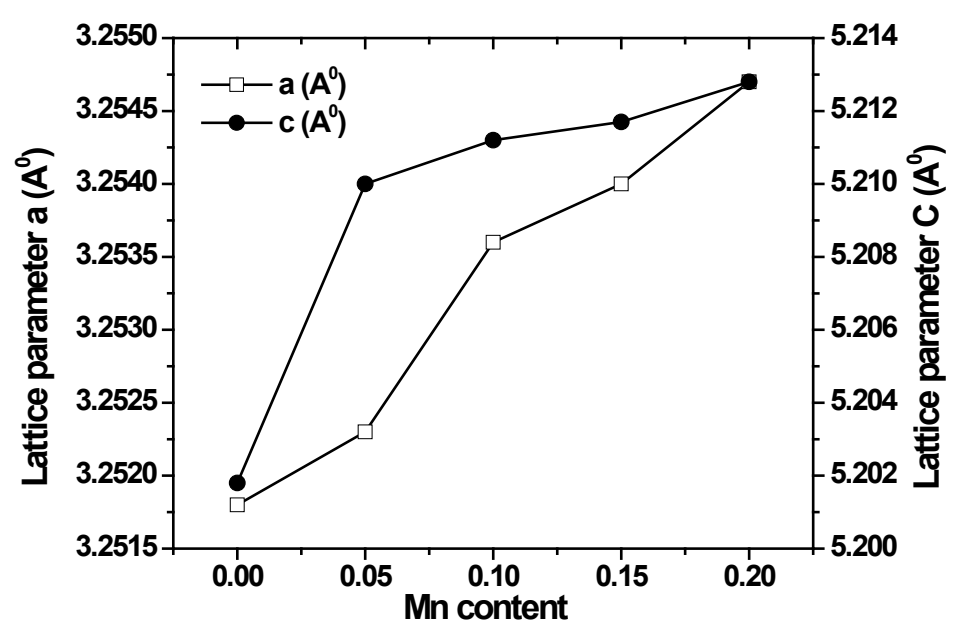

Figure 2. Lattice parameters versus $\mathrm{Mn}$ content of $\mathrm{Zn}_{1-\mathrm{x}} \mathrm{Mn}_{\mathrm{x}} \mathrm{O}$ samples.

\subsection{Volume of Unit Cell and X-Ray Density}

The volume of unit cell was calculated using the equation

$$
V=\frac{\sqrt{3}}{2} a^{2} c
$$

It was found that the volume of unit cell increases with increasing Mn content. It may be due to increasing the lattice parameters a and c. These values of volume of unit cell are tabulated in table 1 . The X- ray density was estimated using the equation

$$
P_{x}=\frac{n M}{N_{A} V}
$$

Where $\mathrm{n}$ is number of atoms per unit cell, $M$ is the molecular weight, $\mathrm{N}_{\mathrm{A}}$ is the Avogadro's number and $\mathrm{V}$ is the volume of unit cell. The $\mathrm{X}$-ray density reduces with increasing $\mathrm{Mn}$ content of $\mathrm{Zn}_{1-\mathrm{x}} \mathrm{Mn}_{\mathrm{x}} \mathrm{O}$ nanoparticles. It may be due the increasing volume of unit cell as well as decreasing molecular weight of the samples. The molecular weight of $\mathrm{Mn}(58.930 \mathrm{amu})$ ions is smaller than that of $\mathrm{Zn}(65.38 \mathrm{amu})$ ions. The values of X-ray density of $\mathrm{Zn}_{1-\mathrm{x}} \mathrm{Mn}_{\mathrm{x}} \mathrm{O}$ nanoparticles are listed in table 1 . The volume of unit cell increases and X-ray density decreases with increasing $\mathrm{Mn}$ content respectively. It means that $\mathrm{Mn}$ ions go to $\mathrm{Zn}$ site in $\mathrm{ZnO}$ structure.

\subsection{Atomic Packing Fraction (APF)}

Atomic packing fraction (APF) was calculated using formula

$$
A P F=\frac{2 \pi a}{3 \sqrt{3} c}
$$

Where a \& $\mathrm{c}$ are the lattice parameters. The value of APF is listed in table 1. It is found that the APF increases with increasing Mn content, it may be due the decrement of voids in the samples. The APF of bulk hexagonal $\mathrm{ZnO}$ materials is about $74 \%$ but in our case the APF of $\mathrm{Zn}_{1-x} \mathrm{Mn}_{\mathrm{x}} \mathrm{O}$ nanoparticles is nearly $75 \%$ in hexagonal structure. It means that APF in nanocrystals are slightly larger than that of bulk materials. It may be due to the size effect in the nanocrystalline samples. The APF increases with increasing $\mathrm{Mn}$ content of $\mathrm{Zn}_{1-\mathrm{x}} \mathrm{Mn}_{\mathrm{x}} \mathrm{O}$ nanoparticles, it indicates homogenous substitution of $\mathrm{Mn}$ ions in the $\mathrm{Zn}$ site of $\mathrm{ZnO}$ structure.

\subsection{Average Crystallite Size (D)}

The average crystallite size was estimated using Scherrer's formula.

$$
D=\frac{K \lambda}{\beta_{h k l} \operatorname{Cos} \theta}
$$

Where $\mathrm{D}$ is the average crystallite size in nanometers, $\mathrm{K}$ is a constant or shape factor and equal to $0.9, \lambda$ is the wavelength of the radiation (1.54056 $\mathrm{A}^{0}$ with $\mathrm{CuK}_{\alpha}$ radiation), $\beta_{\mathrm{hkl}}$ is the peak width at half maximum intensity and $\theta$ is the peak position. The average crystalline size was in the range of 33-43 nm. The average crystallite size decreases 
with increasing $\mathrm{Mn}$ content of $\mathrm{Zn}_{1-\mathrm{x}} \mathrm{Mn}_{\mathrm{x}} \mathrm{O}$ nanoparticles. It may be due to the small grain growth of $\mathrm{Mn}$ doped $\mathrm{ZnO}$ nanoparticles as comprised with pure $\mathrm{ZnO}$ nanoparticles. The values of average crystallite size are listed in table 1 .

\subsection{Surface Area to Volume Ratio}

It is very important to know the surface area to volume ratio of the nanomaterials were general and in particular the selected system. Therefore, we have initiated the program to determine the surface area to volume ratio of $\mathrm{Mn}$ doped $\mathrm{ZnO}$ nanoparticles using the following equation

$$
\frac{N_{\text {surface }}}{N_{\text {volume }}}=\frac{S R_{0}}{V-S R_{0}}=\frac{3 R_{0}}{R-3 R_{0}}
$$

Where $\mathrm{N}_{\text {surface }}$ and $\mathrm{N}_{\text {volume }}$ are the number of $\mathrm{Zn}-\mathrm{O}$ pair at surface and in the volume respectively. $\mathrm{S}$ is the surface area, $\mathrm{V}$ is the volume, $\mathrm{R}_{0}$ is the $\mathrm{ZnO}$ distance $(0.18 \mathrm{~nm})$ and $\mathrm{R}$ - is the average particle radius. The surface area to volume ratio versus $\mathrm{Mn}$ concentration plot is shown in figure 3 .

The values of surface area to volume ratio are listed in table 1 . Table 1 show that the surface area to volume ratio increases with increasing $\mathrm{Mn}$ doping $\mathrm{ZnO}$ samples. It may be due to the decreasing in average crystallite size of the $\mathrm{Zn}_{1-\mathrm{x}} \mathrm{Mn}_{\mathrm{x}} \mathrm{O}$ nanoparticles. The reduction in average crystallite size with increasing $\mathrm{Mn}$ content which increases the surface area to volume ratio. The values of surface to volume ratio is small, it means that the particles are completely spherical in shape. Similar results are reported in literature [17]. The surface area to volume ratio is large due to the small particle and the surface effect described for $(\mathrm{Zn}$, $\mathrm{Mn})-\mathrm{O}$ pairs at the surface changing the $\mathrm{Zn}_{1-\mathrm{x}} \mathrm{Mn}_{\mathrm{x}} \mathrm{O}$ nanoparticles of average crystallite size. The surface area to volume ratio versus average crystallite size is shown in figure 4 .

\subsection{Surface Morphology}

The particle size is determined of pure and Mn substituted $\mathrm{ZnO}$ nanoparticles using TEM. From XRD, the average crystallite size was calculated using Scherrer's formula. However, from TEM the particle size is directly measuring and also morphology of the particles. Figures 5 (a \& c) show the TEM images of pure and $10 \% \mathrm{Mn}$ substituted $\mathrm{ZnO}$ nanoparticles. The TEM images of pure and Mn substituted $\mathrm{ZnO}$ nanoparticles show the samples are in spherical shape with smooth surface. The particle size of pure and $\mathrm{Mn}$ substituted $\mathrm{ZnO}$ nanoparticles are estimated to about 20-60 $\mathrm{nm}$ in diameter.

The figures $5(\mathrm{~b} \& \mathrm{~d})$ present a spotted ring-like SAED (selected area electron diffraction) pattern decorated with random bright spots which demonstrate that the particles have crystalline nature. The selected area electron diffraction (SAED) pattern consists of nine concentric sharp rings, which corresponded to the (100), (002), (101), (102), (110), (103), (200), (112) and (201) of diffraction of the $\mathrm{ZnO}$ in the wurtzite structure. Therefore, it can be further confirmed that the nanoparticles are spherical in shape. Other secondary phases are not observed in figures $5(\mathrm{~b} \& \mathrm{~d})$. It means the $\mathrm{Mn}$ ions are diluted in the $\mathrm{ZnO}$ matrix. No notable contrast is induced by the interstitial $\mathrm{Mn}$ in the $\mathrm{ZnO}$ matrix. It indicates that $\mathrm{Mn}$ atoms may be mainly located at substitution sites. These results are in good agreement with the XRD results and confirm absence of secondary phases.

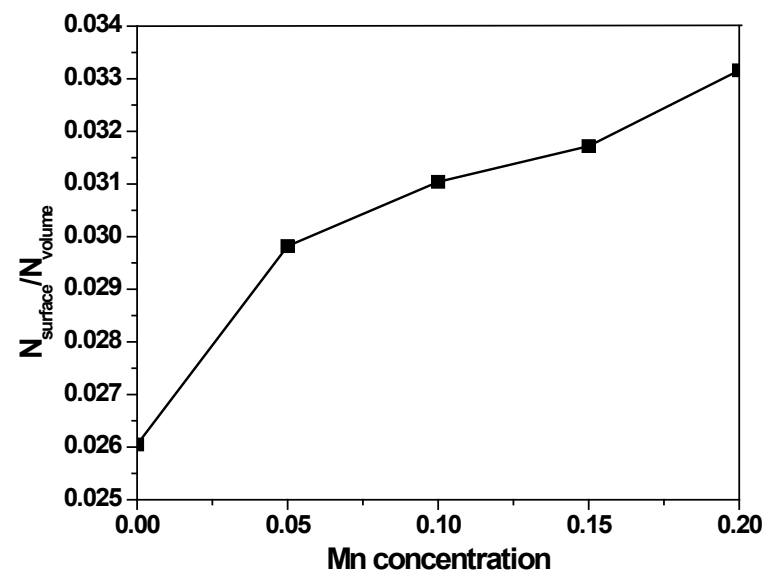

Figure 3. $\mathrm{N}_{\text {surface }} / \mathrm{N}_{\text {volume }}$ versus $\mathrm{Mn}$ concentration of $\mathrm{Zn}_{1-\mathrm{x}} \mathrm{Mn}_{\mathrm{x}} \mathrm{O}$ samples.

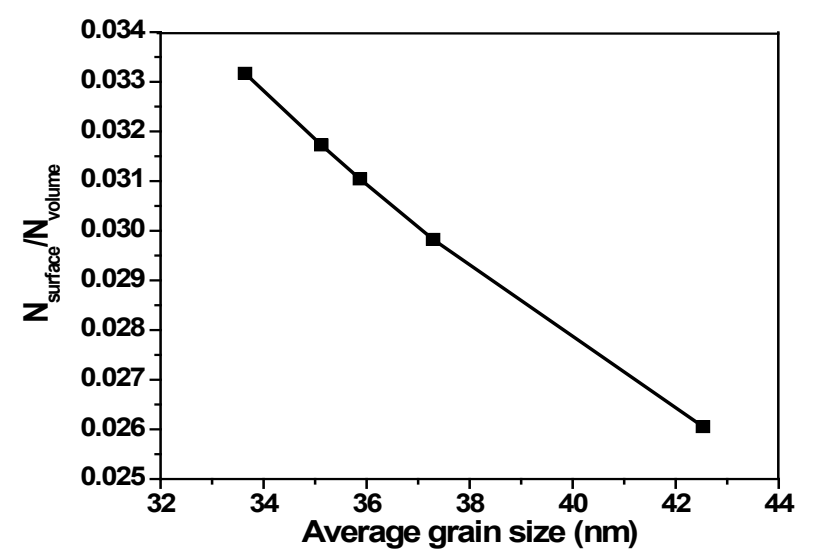

Figure 4. $\mathrm{N}_{\text {surface }} / \mathrm{N}_{\text {volume }}$ versus average crystallite size of $\mathrm{Zn}_{1-\mathrm{x}} \mathrm{Mn}_{\mathrm{x}} \mathrm{O}$ samples.

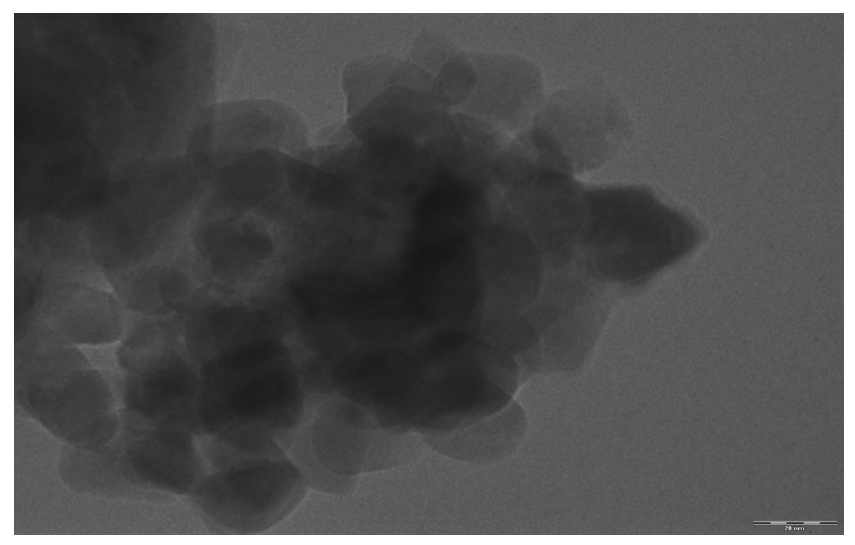

Figure 5(a). TEM image of pure $\mathrm{ZnO}$ nanoparticles. 


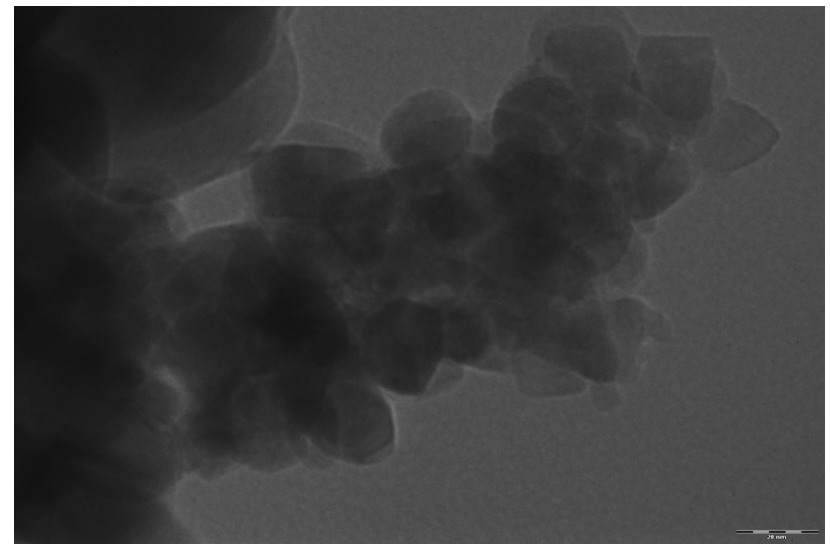

Figure 5(c). TEM image of $\mathrm{Zn}_{0.90} \mathrm{Mn}_{0.10} \mathrm{O}$ nanoparticles.

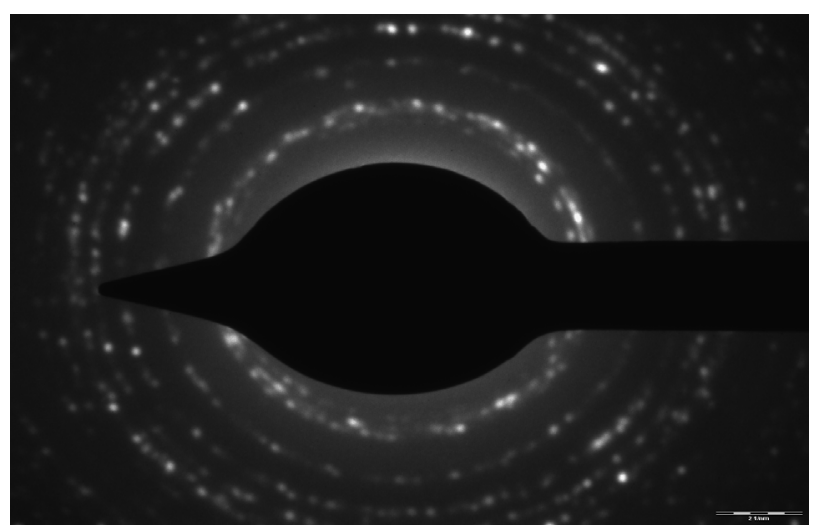

Figure 5(b). Selected area diffraction (SAED) image of pure $\mathrm{ZnO}$ nanoparticles.

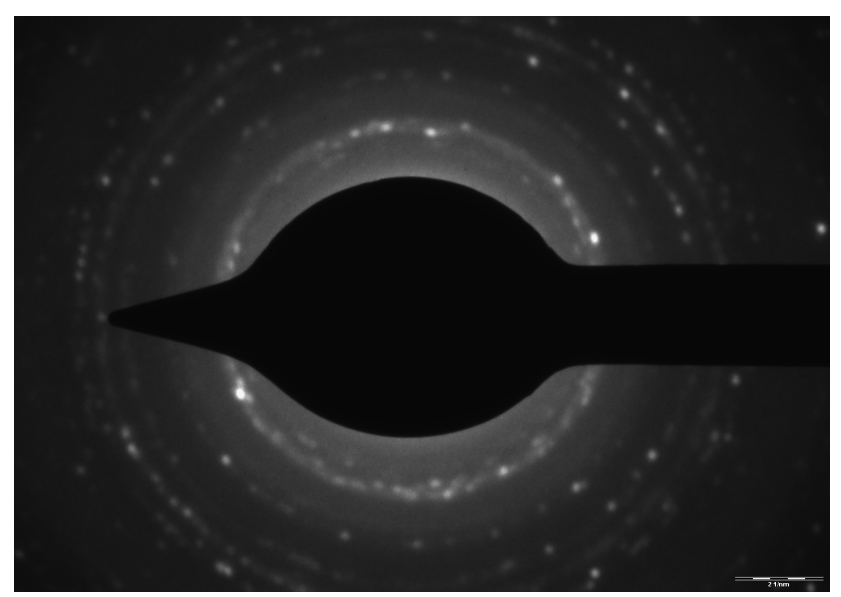

Figure 5(d). Selected area diffraction (SAED) image of $\mathrm{Zn}_{0.90} \mathrm{Mn}_{0.10} \mathrm{O}$ nanoparticles.

\subsection{Optical Studies}

The effect of $\mathrm{Mn}$ on the energy band gap of pure $\mathrm{ZnO}$ and substituted of $\mathrm{Mn}^{2+}$ ions in tetrahedral sites of wurtzite structure of $\mathrm{ZnO}$ was confirmed using UV-Visible optical spectroscopy measured in the range of $200-1000 \mathrm{~nm}$. The UV-Vis absorption spectra of the $\mathrm{ZnO}$ and $\mathrm{Mn}$ doped $\mathrm{ZnO}$ nanoparticles prepared at $450^{\circ} \mathrm{C}$ are shown in figure 6 . The red shift in the absorption edge was observed in the prepared samples. It may be due to the surface effect and average crystallite size or morphology. It is observed that the enhancement in red shift band edge with increasing $\mathrm{Mn}$ concentration. It indicates for the incorporation of $\mathrm{Mn}$ ions into the $\mathrm{Zn}$ site of the $\mathrm{ZnO}$ lattice.

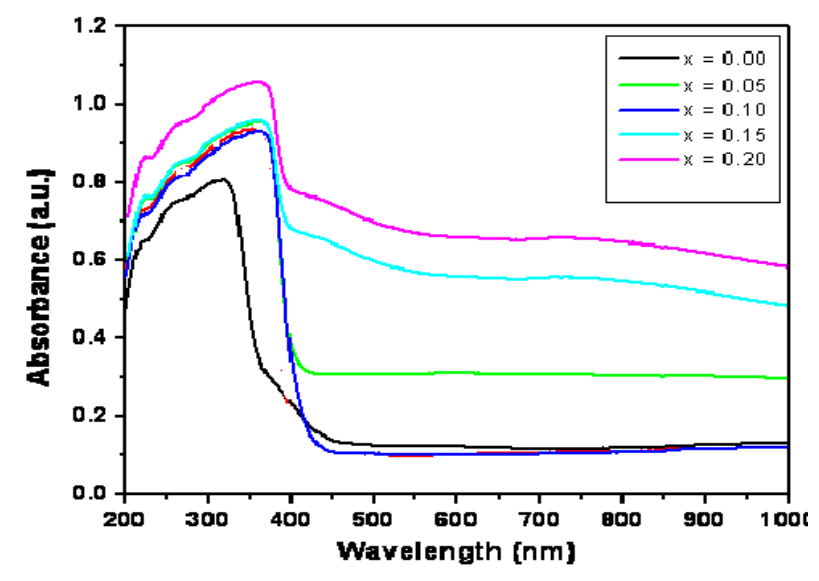

Figure 6. Absorption spectra of $\mathrm{Zn}_{1-\mathrm{x}} \mathrm{Mn}_{\mathrm{x}} \mathrm{O}$ nanoparticles.

The absorption coefficient $\alpha$ is calculated from the absorption spectra using the equation.

$$
\alpha=-\frac{1}{d} A
$$

Where $\mathrm{d}$ is the thickness of samples cell $(1 \mathrm{~cm})$ and $\mathrm{A}$ is the absorbance. The relation between the incident photon energy $(\mathrm{h} v)$ and the absorption coefficients $(\alpha)$ is given below

$$
(\alpha h v)^{1 / m}=c\left(h v-E_{g}\right)
$$

Where $\mathrm{c}$ is a constant and $\mathrm{Eg}$ is the energy band gap of the material and the exponent $\mathrm{m}$ depends on the type of the transition. For direct and allowed transition $\mathrm{m}=1 / 2$, indirect transition $m=2$ and for direct forbidden $m=3 / 2$.

The energy band gap Eg estimated using the intercept of the linear portion of the curve $(\alpha h v) 2$ to $Y=0$. The plots of $(\alpha h v) 2$ versus energy (E) is shown in figures 7 (a-e).

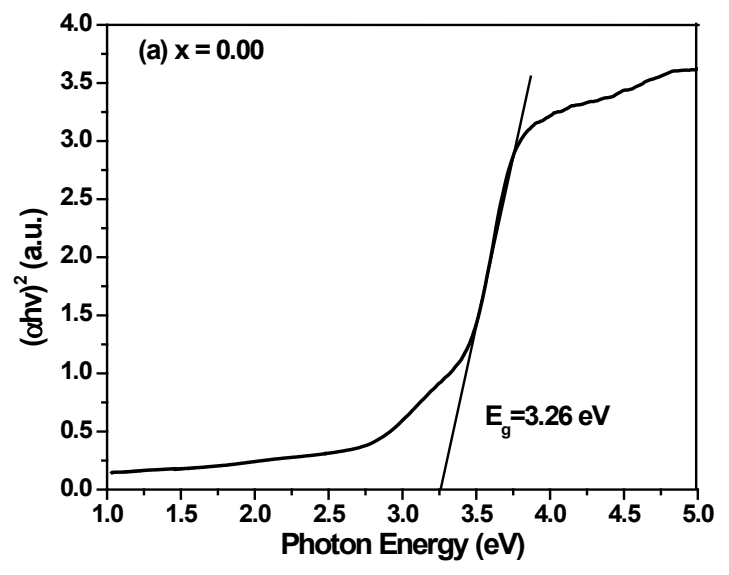

Figure 7(a). $(\alpha h v)^{2}$ versus photon energy of pure $\mathrm{ZnO}$ nanoparticles. 


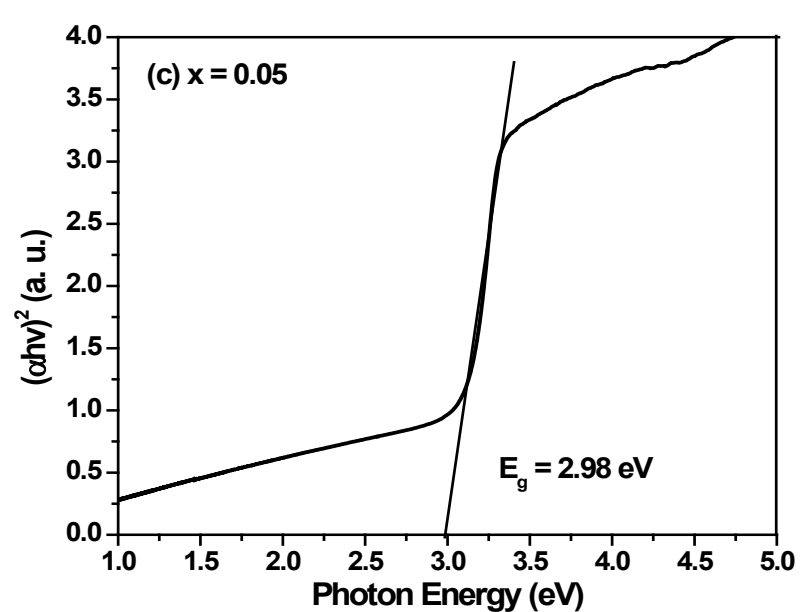

Figure 7(b). $\quad(\alpha h v)^{2}$ versus photon energy of $\mathrm{Zn} 0.95 \mathrm{Mn} 0.05 \mathrm{O}$ nanoparticles.

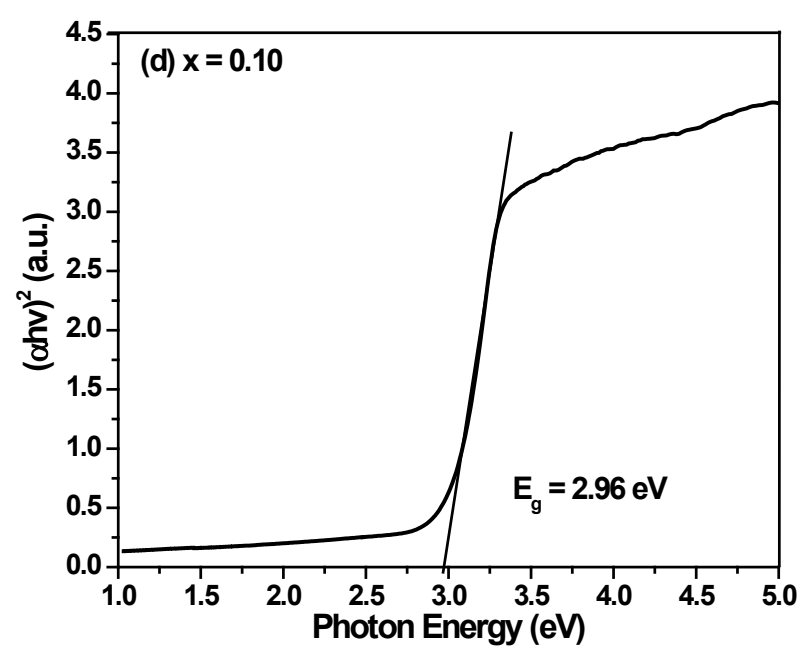

Figure 7(c). $\quad(\alpha h v)^{2}$ versus photon energy of $\mathrm{Zn} 0.90 \mathrm{Mn} 0.10 \mathrm{O}$ nanoparticles.

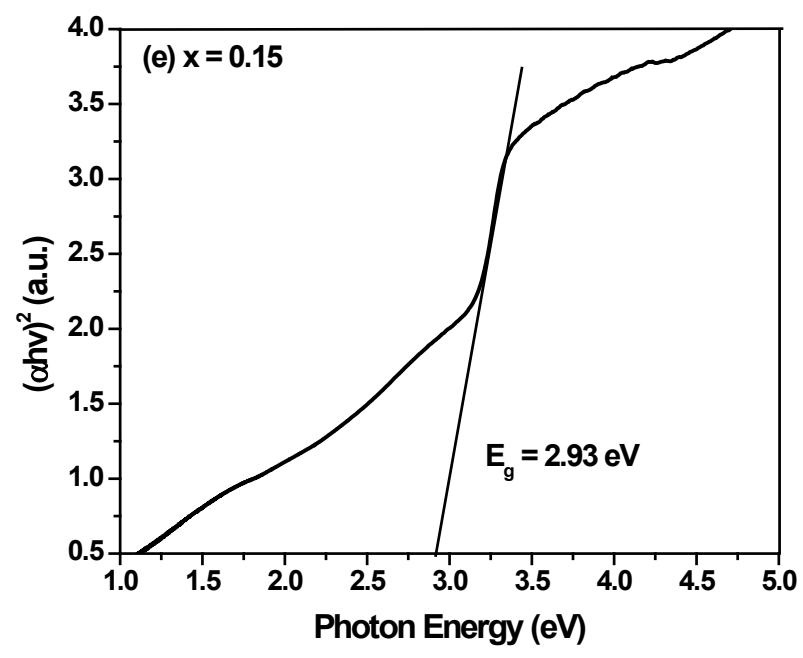

Figure 7(d). $(\alpha h v)^{2}$ versus photon energy of $\mathrm{Zn} 0.85 \mathrm{Mn} 0.15 \mathrm{O}$ nanoparticles.

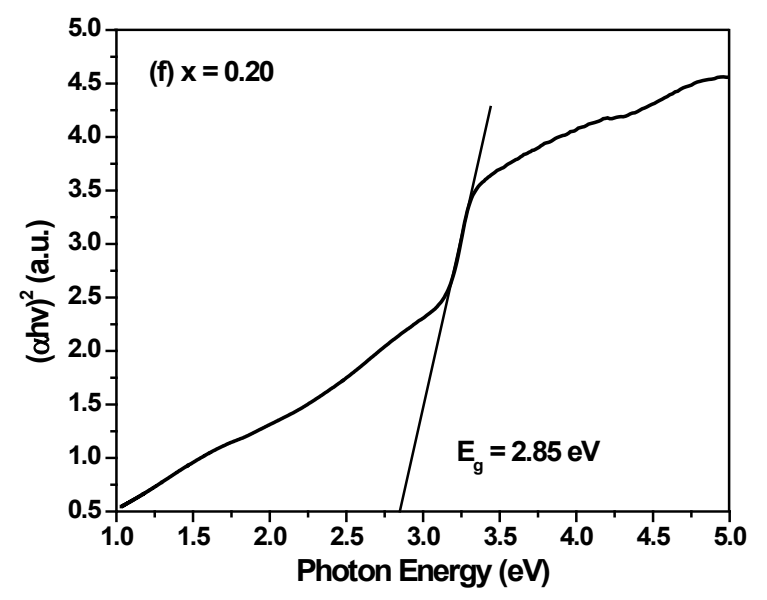

Figure 7(e). $(\alpha h v)^{2}$ versus photon energy of $\mathrm{Zn}_{0.80} \mathrm{Mn}_{0.20} \mathrm{O}$ nanoparticles.

We obtained the energy band gap of $\mathrm{Zn}_{1-\mathrm{x}} \mathrm{Mn}_{\mathrm{x}} \mathrm{O}$ nanoparticles decreases with increasing Mn content. It may be due to the sp-d spin exchange interaction between the band electrons and localized $\mathrm{d}$ electrons of $\mathrm{Mn}$ ions substituting in cation sites. It is found that the band gap of $\mathrm{Zn}_{1-\mathrm{x}} \mathrm{Mn}_{\mathrm{x}} \mathrm{O}$ nanoparticles to be in the range of 3.26 to $2.85 \mathrm{eV}$. Optical energy band gap goes on decreasing with increasing Mn content it may be due to Mn clustering, reduction in average crystallite size and enhancement of surface area to volume ratio. Our experimental results indicate a red shift in the band gap. It indicates that red shift of the band gap confirms the substitution of $\mathrm{Mn}$ ions in $\mathrm{ZnO}$ nanoparticles. The energy band gap versus $\mathrm{Mn}$ content of $\mathrm{Zn}_{1-\mathrm{x}} \mathrm{Mn}_{\mathrm{x}} \mathrm{O}$ nanoparticles is shown in figure 8 .

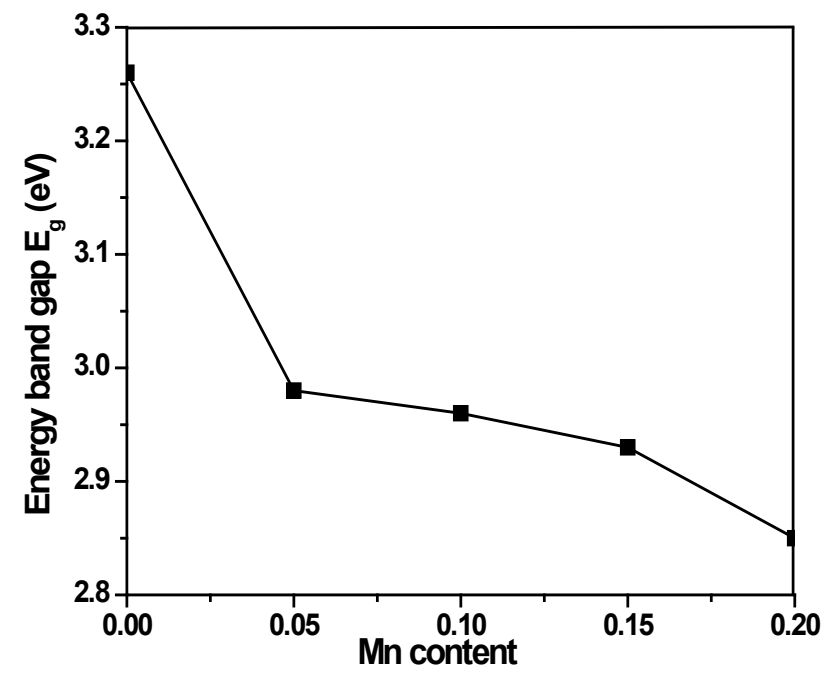

Figure 8. Energy band gap versus $\mathrm{Mn}$ content of $\mathrm{Zn}_{1-\mathrm{x}} \mathrm{Mn}_{\mathrm{x}} \mathrm{O}$ nanoparticles.

Sanyal et al [18] reported that the decrement in energy band gap due to $2 \%$ doping of $\mathrm{Mn}$ in the $\mathrm{ZnO}$. It may be due to the formation of large number of defects inside the samples. However, in our case the energy band gap decrease with increasing $\mathrm{Mn}$ content upto $20 \%$ in the $\mathrm{ZnO}$ nanoparticles. It may be due to Mn clustering, reduction in average crystallite size and enhancement of surface area to 
volume ratio. Wang et al [19] also reported that decreasing energy band gap with increasing Mn content upto $5 \%$ in the $\mathrm{ZnO}$. It may be due to sp-d exchange interaction between transition metal ions and $\mathrm{Zn}$ anions.

\section{Conclusion}

The samples of $\mathrm{Mn}$ doped $\mathrm{ZnO}$ nanoparticles were synthesized successfully by sol-gel method. The crystal structure, morphology and optical properties of the $\mathrm{Zn}_{1-\mathrm{x}} \mathrm{Mn}_{\mathrm{x}} \mathrm{O}$ nanoparticles were investigated at length. The pure and $\mathrm{Mn}$ doped $\mathrm{ZnO}$ nanoparticles have wurtzite (hexagonal) crystal structure. The lattice parameters a and $\mathrm{c}$ increase with increasing $\mathrm{Mn}$ content of $\mathrm{Zn}_{1-\mathrm{x}} \mathrm{Mn}_{\mathrm{x}} \mathrm{O}$ nanoparticles. The volume of unit cell increases with increasing $\mathrm{Mn}$ content which indicates that $\mathrm{Mn}^{2+}$ ions go to $\mathrm{Zn}^{2+}$ ions in $\mathrm{ZnO}$ lattice. The X-ray density decreases with increasing Mn content. Reduction in average crystallite size with increase the Mn content and surface area to volume ratio increases with increasing $\mathrm{Mn}$ content i.e. size effect was observed in the samples. The APF of $\mathrm{Zn}_{1-\mathrm{x}} \mathrm{Mn}_{\mathrm{x}} \mathrm{O}$ nanoparticles increases with Mn content. It may be due to the reduction of voids in the prepared samples. TEM results show that pure and $10 \% \mathrm{Mn}$ doped $\mathrm{ZnO}$ nanoparticles are spherical in shape and the average particle size are in the range of $20-60 \mathrm{~nm}$. The optical energy band gap decreases with increasing $\mathrm{Mn}$ content of $\mathrm{Zn}_{1-\mathrm{x}} \mathrm{Mn}_{\mathrm{x}} \mathrm{O}$ nanoparticles. It may be owing to $\mathrm{Mn}$ clustering, reduction in average crystallite size and enhancement of surface area to volume ratio.

\section{REFERENCES}

[1] Wang X, Song J, Wang ZL: Nanowire and nanobelt arrays of zinc oxide from synthesis to properties and to novel devices. J. Mater. Chem. 2007, 17: 711-720.

[2] Hongsith N, Viriyaworasakul C, Mangkorntong $P$, Mangkorntong N, Choopun S: Ethanol sensor based on $\mathrm{ZnO}$ and $\mathrm{Au}$-doped $\mathrm{ZnO}$ nanowires. Cram. Int. 2008, 34: 823-826.

[3] Arnold MS, Avouris P, Pan ZW, Wang ZL: Field-Effect Transistors Based on Single Semiconducting Oxide Nanobelts. J. Phys. Chem. B 2003, 107: 659-663.

[4] Jun JH, Seong H, Cho K, Moon BM, Kim S: Ultraviolet photodetectors based on ZnO nanoparticles. Cerm. Int. 2009, 35: 2797-2801.

[5] Kumar N, Dorfman A, Hahm JI: Ultrasensitive DNA sequence detection using nanoscale $\mathrm{ZnO}$ sensor arrays.
Nanotechnology 2006, 17: 2875-2881.

[6] Dalpia GM, Wei S, Gong XG, Da silva AJR, Fazzio A: Phenomenological band structure model of magnetic coupling in semiconductors. Solid state commun. 2006, 138: 353-358.

[7] Dole BN, Mote VD, Huse VR, Purushotham Y, Lande MK, Jadhav KM, Shah SS: Structural studies of Mn doped ZnO nanoparticles. Current Applied Physics 2011, 11: 762-766.

[8] Mote VD, Purushotham Y, Dole BN: Structural and morphological studies on $\mathrm{Mn}$ doped $\mathrm{ZnO}$ nanometer-sized crystals. Cryst. Res. Technol. 2011, 46: 705-710.

[9] Riahi-Noori N, Sarrof-Momoory R, Alizadeh P, Mehdikhoni A: Synthesis of $\mathrm{ZnO}$ nano powder by a gel combustion method. J. Ceram. Process. Res.2008, 9: 246-249.

[10] Chattopadhyay S, Dutta S, Banerjee A, Jana D, Bandypadhyay S, Chattopadhyay S, Sarkar A: Synthesis and characterization of single-phase Mn-doped $\mathrm{ZnO}$. Physica B.2009. 404: 1509-1514.

[11] Zhang H, Yang DR, Li DS, Ma XY, Li SZ, Que DL: Controllable Growth of $\mathrm{ZnO}$ Microcrystals by a Capping-Molecule-Assisted Hydrothermal Process. Cryst. Growth. Des. 2005, 2: 547-550.

[12] Shen GZ, Bando Y, Lee CJ: Synthesis and Evolution of Novel Hollow $\mathrm{ZnO}$ Urchins by a Simple Thermal Evaporation Process. J. Phys. Chem. B 2005, 109: 10578-10583.

[13] Kodas TT: Generation of complex Metal Oxides by Aerosol Processes: Superconducting ceramic particles and films. Adv.Mater. 1989, 6: 180-191.

[14] Liu B, Zeng HC: Room Temperature Solution Synthesis of Monodispersed Single-Crystalline $\mathrm{ZnO}$ Nanorods and Derived Hierarchical Nanostructures. Langmuir 2004, 20: 4196-4204.

[15] Sharma VK, Varma GD: Investigations on the effect of gaseous environment during synthesis on the magnetic properties of Mn-doped ZnO. J. Alloys compounds 2008, 458: 523-527.

[16] Abrishani ME, Hosseini SM, Kakhki EA, Kompany A: Structural and optical properties of zinc oxide nanopowders doped with Mn. Phys. Stautus C 2010, 7: 1595-1598.

[17] Kazemi A, Abayan M, Ketabi SA: Controlled structural and optical properties of ZnO nano-particles. Phys. Scr. 2010, 82: 035801 .

[18] Sanyal D, Chakrabarti M, Chakrabarti A: Synthesis and positron characterizations of ferromagnetic and paramagnetic samples. Solid State Communication, 2010, 150: $2266-2269$.

[19] Wang ZH, Geng DY, Zhang ZD: Room-temperature ferromagnetism and optical properties of $\mathrm{Zn1}-\mathrm{xMnxO}$ nanoparticles. Solid State Communication, 2009, 149: 682-684. 